\title{
NITROGEN-15 LABELING OF Crotalaria juncea GREEN MANURE
}

\author{
Edmilson José Ambrosano ${ }^{1,6 *}$; Paulo Cesar Ocheuze Trivelin',6; Heitor Cantarella ${ }^{3,6}$; Raffaella \\ Rossetto'; Takashi Muraoka'2,6; José Albertino Bendassolli2,6; Gláucia Maria Bovi Ambrosano5,6; \\ Luciano Grassi Tamiso4; Felipe de Campos Vieira4; Ithamar Prada Neto ${ }^{4}$ \\ ${ }^{1}$ Centro de Ação Regional, Estação Experimental de Agronomia de Piracicaba - IAC, C.P. 28 CEP: 13400-970 - \\ Piracicaba, SP. \\ 2 Lab. de Isótopos Estáveis - Divisão de Desenvolvimento de Métodos e Técnicas Analíticas e Nucleares, USP/ \\ CENA, C.P. 96 - CEP: 13400-970 - Piracicaba, SP. \\ ${ }^{3}$ Centro de Pesquisa e Desenvolvimento de Solos e Recursos Agroambientais - IAC, C.P. 28 - CEP: 13001-970 - \\ Campinas, $S P$. \\ ${ }^{4}$ Depto. de Produção Vegetal - USP/ESALQ, C.P. 9 - CEP: 13418-900 - Piracicaba, SP. \\ ${ }^{5}$ Depto. de Odontologia Social, Bioestatistica - UNICAMP/ FOP, C.P. 52 - CEP: 13414-903 - Piracicaba, SP. \\ ${ }^{6} \mathrm{CNPq}$ Fellow. \\ *Corresponding author<edmilson@iac.br>
}

ABSTRACT: Most studies dealing with the utilization of ${ }^{15} \mathrm{~N}$ labeled plant material do not present details about the labeling technique. This is especially relevant for legume species since biological nitrogen fixation difficults plant enrichment. A technique was developed for labeling leguminous plant tissue with ${ }^{15} \mathrm{~N}$ to obtain labeled material for nitrogen dynamics studies. Sun hemp ( Crotalaria junceaL.) was grown on a Paleudalf, under field conditions. An amount of $58.32 \mathrm{~g}$ of urea with $70.57 \pm 0.04$ atom $\%{ }^{15} \mathrm{~N}$ was sprayed three times on plants grown on eight $6-\mathrm{m}^{2}$-plots. The labelled material presented 2.412 atom $\%{ }^{15} \mathrm{~N}$ in a total dry matter equivalent to $9 \mathrm{Mg} \mathrm{ha}^{-1}$ This degree of enrichment enables the use of the green manure in pot or field experiments requiring ${ }^{15} \mathrm{~N}$-labeled material.

Key words: ${ }^{15} \mathrm{~N}$-fertilizer, labeled legumes, green manure

\section{MARCAÇÃO DO ADUBO VERDE Crotalaria juncea COM ${ }^{15} \mathrm{~N}$}

\begin{abstract}
RESUMO: A grande maioria dos estudos com a utilização de material vegetal marcado com o isótopo ${ }^{15} \mathrm{~N}$ não apresentam detalhes tão importantes sobre como foram obtidos esses materiais. Em se tratando de marcação de leguminosas as dificuldades em se obter material marcado $c \mathrm{~m}^{15} \mathrm{~N}$ são ainda maiores pelo fato de serem plantas fixadoras de nitrogênio. Isso posto foi estabelecida uma técnica de marcação de leguminosas com nitrogênio $\left({ }^{15} \mathrm{~N}\right)$, com o objetivo de obter material vegetal marcado isotopicamente para estudos de dinâmica do nitrogênio. Cultivou-se a leguminosa crotalária júncea (Crotalaria juncea L.), em Argissolo Vermelho Amarelo distrófico, em campo. Ao se aplicarem via foliar 58,32 gramas de uréia em oito canteiros experimentais, (uréia com $70,57 \pm 0,04 \%$ de átomos de ${ }^{15} \mathrm{~N}$ ) parceladas em três vezes, obteve-se material vegetal marcado seco que continha $2,412 \%$ em átomos de ${ }^{15} \mathrm{~N}$ em uma massa seca equivalente a $9 \mathrm{Mg}$ $\mathrm{ha}^{-1}$. Essa marcação permite o uso dessa massa vegetal em estudos de dinâmica de nitrogênio.

Palavras-chave: fertilizante $-{ }^{15} \mathrm{~N}$, leguminosa marcada, adubo verde
\end{abstract}

\section{INTRODUCTION}

The use of the stable isotope ${ }^{15} \mathrm{~N}$ can help to identify nitrogen sources and is important for research on nitrogen dynamics in the soil-plant system. The ${ }^{15} \mathrm{~N}$ labeling of green manures allows the determination of the amount of the nutrient in the soil and in the subsequent crop derived from the green manure which is only feasible with the use of isotopic methods. High degree of labeling of legumes with ${ }^{15} \mathrm{~N}$ is complicated since these plants usually obtain a significant part of their $\mathrm{N}$ from the air, through biological $\mathrm{N}$ fixation from either soil or inoculated bacteria. Most papers on ${ }^{15} \mathrm{~N}$ do not explain how the leguminous plant material was marked. Ambrosano et al. (1997) established a ${ }^{15} \mathrm{~N}$ labeling technique for legumes growing in a greenhouse, and obtained a dried material with 3.177 and 4.337 atom $\%{ }^{15} \mathrm{~N}$, for velvet bean and sun hemp, respectively.

Ambrosano (1995), using the techniques later described by Ambrosano et al. (1997) for velvet bean and sun hemp, determined that 60 to $80 \%$ of plant nitrogen remained in the soil, 20 to $30 \%$ were absorbed by corn plants, and 5 to $15 \%$ were lost from the soil-plant system. Azam at al. (1985) investigated the incorporation of Sesbania aculeata residues labeled with atom \% 0.617 in ${ }^{15} \mathrm{~N}$ excess, and determined that only $5 \%$ of the $\mathrm{N}$ from the legumes was absorbed by the corn plants. In the balance calculated by the authors, losses were around $5 \%$ when only Sesbania was applied. However, the low labeling levels used by Azam et al. (1985) may have 
affected the results. The accuracy of isotope assays is directly proportional to the labeling levels, i.e., the lower the labeling level, the lower the accuracy. For more accurate (Bartholomew, 1965) and trustable results labeling level of at least 2 atoms $\%{ }^{15} \mathrm{~N}$ excess is needed.

Little attention has been given to the effectiveness of green manures in supplying nutrients to crops (Muraoka,1984). The ${ }^{15} \mathrm{~N}$ labeling technique provides more precise information on nitrogen dynamics in the soil-plant system. Once the green manure is labelled, the fate of the nitrogen release from the legumes can be traced.

Crotalaria juncea is widely distributed over the tropics. It grows as a shrub, with a straight trunk, and its fibers have high quality cellulose, adequate for paper and other uses. Crotalaria grows fast, and can reach 3.0 to $3.5 \mathrm{~m}$ height, with an average yield ranging from 10 to $15 \mathrm{Mg} \mathrm{ha}^{-1}$ of dry material when sown in the summer. Since it is considered a bad host for galls and cystsforming nematodes, it is highly recommended as a green manure. The crop cycle can last 180 days, but, when grown as green manure, cutting is suggested at about 120 days, during the peak of flowering (Salgado et al. 1987).

Legumes are important in crop rotations including sugar cane. Crotalaria is usually chosen because of its high biomass production, high biological nitrogen fixation, and capacity for controlling nematode infestation (Mascarenhas et al., 1994). However, field experiments require large amounts of ${ }^{15} \mathrm{~N}$-labeled material and there is a lack of information on ways of producing ${ }^{15} \mathrm{~N}$-labaled legumes under field conditions. Therefore, the objective of the present study was to establish procedures for ${ }^{15} \mathrm{~N}$ labeling techniques of Crotalaria juncea grown in the field.

\section{MATERIAL AND METHODS}

The IAC 1-2 variety of Crotalaria juncea $L$ was used in this study and was grown with no fertilization in a Paleudalf in Piracicaba, SP, Brazil. Crotalariawas sown (25 seeds per meter) on December 4, 2000 and emerged nine days after. Seeding was delayed to mid summer to avoid high growth rates, which could lead to higher ${ }^{15} \mathrm{~N}$ isotopic dilution.

The experimental site consisted of 12 plots containing 6 rows of Crotalaria, $2 \mathrm{~m}$ long, spaced $0.5 \mathrm{~m}$. The $6 \mathrm{~m}^{2}$ Crotalaria plots were placed in the middle of $140 \mathrm{~m}^{2}$ plots which were planed to be grown subsequently with sugar cane. In an adjacent area Crotalaria was cultivated in the same manner so that dry matter yields could be periodically assessed without affecting the experiment.

Eight plots were used for the labeling the Crotalaria plants and four were left as control (T1). The eight labeled plots were divided in two groups or four plots, which were meant for different treatments in the sugar cane trial that would follow. Although they received the same amounts of ${ }^{15} \mathrm{~N}$-urea, these plots were referred to as T2 and T3. Initially 5 applications of ${ }^{15} \mathrm{~N}$-labeled urea were planned but only 3 applications were made because of the fast growth rate of Crotalaria and the very fast isotopic dilution could negatively affect the ${ }^{15} \mathrm{~N}$ enrichment.

Urea $(58.32 \mathrm{~g})$, with $70.57 \%+0.04{ }^{15} \mathrm{~N}$ atoms \% was used to label the 8 Crotalaria plots. For the first application $11.66 \mathrm{~g}$ of urea were diluted in $1000 \mathrm{~mL}$ of water and exactly $125 \mathrm{~mL}$ of this solution were sprayed to each plot. For the second and third applications, 2000 $\mathrm{mL}$ of solution, with the same urea concentration, were prepared, using $250 \mathrm{~mL}$ per plot. The ${ }^{15} \mathrm{~N}$-urea solutions were sprayed 29, 59 and 74 days after plant emergency. The first application was made with a small spray bottle (Dompel brand, 350-mL capacity) because the 29-day old plants $(0.45 \mathrm{~m}$ high) presented a relatively small leaf area. For the other two applications a garden sprayer (Bruden brand, 4-L capacity) was used. During the foliar spray of urea, the soil and borders of the plots were covered with plastic sheets to avoid contamination of the soil and the surrounding plants. The dates of urea application as well as the height and plant mass in each period are shown in Table 1.

Crotalaria biomass production was evaluated in 1 $\mathrm{m}^{2}$ of an adjacent area, grown with Crotalaria with no urea spray. One week after ${ }^{15} \mathrm{~N}$-urea was sprayed, two plants per plot of the experiment were sampled, separated into shoot and root, and analyzed for total $\mathrm{N}$ and ${ }^{15} \mathrm{~N}$ concentration. The Crotalaria plants were harvested at the flowering stage, 79 days after emergency. Shoot and root were analyzed separately. Roots were washed, dried under shade, and weighed. Plant shoot and root, as well as dead leaves collected from the ground were oven-dried $\left(60^{\circ} \mathrm{C}\right)$ for the determination of dry mass, $\mathrm{N}$ content and ${ }^{15} \mathrm{~N}$ abundance. Nitrogen content was determined by the micro-Kjeldahl digestion-distillation method (Bremner \& Mulvaney, 1982) and ${ }^{15} \mathrm{~N}$ by the mass spectrometry using the sampling preparation described by Trivelin et al. (1973). Plant chemical analysis for determination of macroand micronutrients was performed according to Bataglia et al. (1983).

After harvesting the Crotalaria plants, soil was sampled at the $0-20 \mathrm{~cm}$ and $20-40 \mathrm{~cm}$ depths for fertility analysis. Two composit samples were assembled with the soil of the 8 plots treaded with ${ }^{15} \mathrm{~N}$-urea and the 4 control plots, respectively.

\section{RESULTS AND DISCUSSION}

The degree of labeling of the Crotalaria plants increased with time due to successive ${ }^{15} \mathrm{~N}$-urea applications. The plant samples collected 7 days after the first urea spray had concentrations of ${ }^{15} \mathrm{~N}$ of 0.657 atoms $\%$ for shoot and 0.875 atoms \% for root. The corresponding values for the plants at flowering, after three urea applications, were 2.412 and 1.644 atoms \% 
${ }^{15} \mathrm{~N}$, with dry matter yield of about 9.1 and $1 \mathrm{t} /$ ha for shoot and root, respectively (Table 1). The results indicate that ${ }^{15} \mathrm{~N}$ enrichment of the Crotalaria plants was efficient and even the roots reached a reasonable ${ }^{15} \mathrm{~N}$-labeling. Therefore, this field labeling technique seems to be adequate for studies on nitrogen dynamics using plant material that will be added to the soil and undergo isotopic dilution until it is analyzed in the subsequent crop.

Samples of Crotalaria taken 7 days after the first and the second urea application were thoroughly rinsed with distilled water before ${ }^{15} \mathrm{~N}$ determinations. The results of ${ }^{15} \mathrm{~N}$ concentration (data not shown) were similar to those obtained with plants that were only oven-dried, indicating that the ${ }^{15} \mathrm{~N}$ was rapidly incorporated to the plants and could not be removed by the cleaning procedures used for plant analysis.

A lower labeling level ( $<2{ }^{15} \mathrm{~N}$ atoms \%) can negatively affect accurate determination in isotopic analyses. The dry plant material contained more than 190 $\mathrm{kg} \mathrm{ha}^{-1}$ of $\mathrm{N}$. These values can vary greatly. Muraoka et al. (2002) observed a variation from 149 to $362 \mathrm{~kg} \mathrm{ha}^{-1}$
$\mathrm{N}$, affected by the dry matter production but not by the $\mathrm{N}$ contents, which were similar.

Table 2 shows the data on yield and $\mathrm{N}$ concentration of the Crotalaria at the flowering stage, when it was cut to be used as green manure. That the dry matter yield of shoot and root as well as the $\mathrm{N}$ concentration of the plants sprayed with ${ }^{15} \mathrm{~N}$-urea were similar to those of the control plots, suggesting that the labeling technique was adequate for labeling the Crotalaria plants without changing the $\mathrm{N}$ content of the plant. Dead leaves that fell from the plants along the growing cycle represented a small part of the total dry matter produced, but were highly enriched with ${ }^{15} \mathrm{~N}$ (Table 2).

The nutrient contents shown in Table 3 are similar to those found in field experiments with Crotalaria by Tanaka et al. (1992) and Muraoka et al. (2002), although $\mathrm{Mn}$ and $\mathrm{Fe}$ values are a little higher because the parent material of the Paleudalf presents high contents of those nutrients. The results also indicate that the foliar spray of small amounts of ${ }^{15} \mathrm{~N}$ labelled urea did not change the macro and micronutrient contents of the plants.

Table 1 - Application dates of ${ }^{15} \mathrm{~N}$-containing urea. Characterization of Crotalaria shoot and root performed seven days after fertilizer application.

\begin{tabular}{|c|c|c|c|c|c|c|}
\hline \multirow[t]{2}{*}{ Applicatio Date } & \multirow{2}{*}{ Fresh mass } & \multirow{2}{*}{ Dry mass } & \multicolumn{2}{|c|}{$\mathrm{N}$ content } & \multirow{2}{*}{$\frac{15 \mathrm{~N}}{\text { Atom \% }}$} & \multirow{2}{*}{$\frac{\text { Plant height }}{\mathrm{m}}$} \\
\hline & & & $\mathrm{g} \mathrm{kg}^{-1}$ & $\mathrm{~kg} \mathrm{ha}^{-1}$ & & \\
\hline & & & 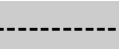 & 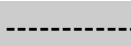 & 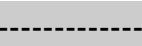 & \\
\hline $01 / 11 / 01$ & 3055 & 638 & 47.0 & 29.9 & 0.657 & 0.45 \\
\hline $01 / 31 / 01$ & 19000 & 3560 & 15.0 & 53.4 & 1.596 & 1.75 \\
\hline $02 / 15 / 01$ & 22500 & 4703 & $43.0^{1}$ & - & 3.260 & 1.95 \\
\hline \multirow[t]{2}{*}{$02 / 20 / 01^{2}$} & 33393 & 9150 & 21.4 & 195.8 & 2.412 & 2.00 \\
\hline & --------- & - & --.-- & --------. & 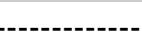 & (n) \\
\hline $01 / 11 / 01$ & 310 & 61 & 8.4 & 0.5 & 0.875 & - \\
\hline $01 / 31 / 01$ & 2300 & 463 & 9.7 & 4.5 & 1.332 & - \\
\hline 02/15/01 & 2150 & 515 & 1 & - & - & - \\
\hline $02 / 20 / 01^{2}$ & 3532 & 1052 & 7.7 & 8.1 & 1.644 & - \\
\hline
\end{tabular}

Only leaves were analyzed for labeling control. ${ }^{2}$ Harvest date.

Table 2 - Fresh and dry mass and N content of different Crotalaria plant parts at harvesting. Results are means of four replicates.

\begin{tabular}{|c|c|c|c|c|c|c|}
\hline \multirow[t]{2}{*}{ Plant part $^{1}$} & \multirow[t]{2}{*}{ Treatment $^{2}$} & \multirow{2}{*}{ Fresh mass } & \multirow{2}{*}{ Dry mass } & \multirow{2}{*}{$\frac{15 \mathrm{~N}}{\text { atom } \%}$} & \multicolumn{2}{|c|}{$\mathrm{N}$ content } \\
\hline & & & & & $\mathrm{g} \mathrm{kg}^{-1}$ & $\mathrm{~kg} \mathrm{ha}^{-1}$ \\
\hline Shoot & T1 & 30625 & 9134 & 0.372 & 23.7 & 216.5 \\
\hline Dead leaf & T1 & 508 & 331 & 0.369 & 15.7 & 5.2 \\
\hline Root & T1 & 3007 & 885 & 0.367 & 9.0 & 7.9 \\
\hline Shoot & T2 & 35000 & 9366 & 2.136 & 22.0 & 206.3 \\
\hline Dead leaf & T2 & 594 & 303 & 2.050 & 13.9 & 4.2 \\
\hline Root & $\mathrm{T} 2$ & 3782 & 1140 & 1.494 & 7.5 & 8.6 \\
\hline Shoot & T3 & 31787 & 8933 & 2.687 & 20.7 & 184.9 \\
\hline Dead leaf & T3 & 554 & 298 & 2.292 & 14.6 & 4.3 \\
\hline Root & T3 & 3282 & 964 & 1.793 & 7.9 & 7.6 \\
\hline
\end{tabular}

Dead leaves collected on the ground. ${ }^{2} \mathrm{~T} 1=$ Control (Crotalaria with no $\left.{ }^{15} \mathrm{~N}\right) . \mathrm{T} 2$ and $\mathrm{T} 3=$ treatments with ${ }^{15} \mathrm{~N}$-labeled Crotalaria. 
Table 3 - Macro and micronutrient contents and $\mathrm{C} / \mathrm{N}$ ration in different plant parts of Crotalaria sampled at harvesting.

\begin{tabular}{|c|c|c|c|c|c|c|c|c|c|c|c|}
\hline Plant material $^{1}$ & Treatment $^{2}$ & $\mathrm{~K}$ & $P$ & $\mathrm{Ca}$ & $\mathrm{Mg}$ & $\mathrm{B}$ & $\mathrm{Cu}$ & $\mathrm{Fe}$ & $\mathrm{Mn}$ & $\mathrm{Zn}$ & $\mathrm{C} / \mathrm{N}$ \\
\hline & & - & $-\cdots$ & $g^{-1} \ldots$ & $-\cdots$ & ------- & - & $\mathrm{mg} \mathrm{kg}$ & - & - & \\
\hline Shoot & T1 & 7.2 & 2.1 & 9.2 & 5.0 & 36.2 & 10.8 & 527 & 69.8 & 22.7 & 31 \\
\hline Dead leaf & $\mathrm{T} 1$ & 2.3 & 1.5 & 40.9 & 14.5 & 58.2 & 13.6 & 4872 & 300.3 & 21.9 & 34 \\
\hline Root & T1 & 6.7 & 1.0 & 1.4 & 3.2 & 25.0 & 8.4 & 5619 & 30.5 & 12.1 & 52 \\
\hline Shoot & T2 & 7.8 & 1.9 & 8.3 & 4.2 & 41.5 & 8.2 & 832 & 43.0 & 18.2 & 27 \\
\hline Dead leaf & $\mathrm{T} 2$ & 1.8 & 1.1 & 32.6 & 12.2 & 54.2 & 11.4 & 7035 & 199.8 & 20.8 & 26 \\
\hline Root & T2 & 7.4 & 0.9 & 1.2 & 2.8 & 26.9 & 8.0 & 8737 & 34.0 & 11.7 & 55 \\
\hline Shoot & T3 & 6.2 & 1.8 & 7.0 & 4.3 & 39.3 & 8.6 & 935 & 41.8 & 17.4 & 23 \\
\hline Dead leaf & T3 & 1.8 & 1.4 & 33.4 & 13.3 & 50.7 & 13.1 & 8990 & 227.3 & 27.0 & 26 \\
\hline Root & T3 & 6.7 & 1.0 & 1.2 & 3.2 & 27.3 & 7.8 & 6215 & 30.0 & 11.5 & 58 \\
\hline
\end{tabular}

${ }^{1}$ Dead leaves collected on the ground. ${ }^{2} \mathrm{~T} 1=$ Control (Crotalaria with no $\left.{ }^{15} \mathrm{~N}\right) . \mathrm{T} 2$ and $\mathrm{T} 3=$ treatments with ${ }^{15} \mathrm{~N}$-labeled Crotalaria.

Table 4 - Analyses of soil from plots grown with Crotalaria and control plots kept uncultivated. Samples were taken at the 0-0.2 and 0.2-0.4 m depths.

\begin{tabular}{|c|c|c|c|c|}
\hline \multirow[t]{2}{*}{ Soil variable } & \multicolumn{2}{|c|}{ Uncultivated soil } & \multicolumn{2}{|c|}{ Soil with Crotalaria } \\
\hline & $0-0.2 \mathrm{~m}$ & $0.2-0.4 \mathrm{~m}$ & $0-0.2 \mathrm{~m}$ & $0.2-0.4 \mathrm{~m}$ \\
\hline $\mathrm{pH}$ & 4.1 & 4.0 & 4.5 & 4.7 \\
\hline O.M. $\left(\mathrm{g} \mathrm{dm}^{-3}\right)$ & 26 & 22 & 24 & 22 \\
\hline$P\left(\mathrm{mg} \mathrm{dm}^{-3}\right)$ & 3 & 14 & 6 & 6 \\
\hline $\mathrm{S}(\mathrm{mg} \mathrm{dm}-3)$ & 12 & 15 & 8 & 8 \\
\hline $\mathrm{K}\left(\mathrm{mmol} \mathrm{dm}_{\mathrm{c}}-3\right)$ & 0.7 & 0.5 & 0.3 & 0.3 \\
\hline $\mathrm{Ca}\left(\mathrm{mmol}_{\mathrm{c}} \mathrm{dm}^{-3}\right)$ & 7 & 6 & 12 & 11 \\
\hline $\mathrm{Mg}\left(\mathrm{mmol}_{\mathrm{c}} \mathrm{dm}^{-3}\right)$ & 6 & 5 & 11 & 10 \\
\hline $\mathrm{H}+\mathrm{Al}\left(\mathrm{mmol}^{-3} \mathrm{dm}^{-3}\right)$ & 50 & 68 & 36 & 31 \\
\hline $\mathrm{Al}\left(\mathrm{mmol}_{\mathrm{c}} \mathrm{dm}^{-3}\right)$ & 10 & 11 & 2 & 2 \\
\hline Base saturation $\left(\mathrm{mmol}_{\mathrm{c}} \mathrm{dm}^{-3}\right)$ & 13.7 & 11.5 & 23.3 & 21.3 \\
\hline $\operatorname{CEC}\left(\mathrm{mmol}_{\mathrm{c}} \mathrm{dm}^{-3}\right)$ & 63.7 & 79.5 & 59.3 & 52.3 \\
\hline $\mathrm{V} \%$ & 22 & 14 & 39 & 41 \\
\hline
\end{tabular}

\section{CONCLUSION}

The production of ${ }^{15} \mathrm{~N}$-labeled green manure without changing its chemical characteristics was successful. The procedure used for isotopic nitrogen labeling of Crotalaria juncea in the field was adequate because it was possible to produce large quantities of plant material with a degree of ${ }^{15} \mathrm{~N}$ enrichment of both, shoot and root, satisfactory for their use in "in loco" studies on the fate of the $\mathrm{N}$ from green manure.

\section{ACKNOWLEDGMENT}

To Paulo E. Magalhães, Ângela M.C. da Silva, Benedito Mota, Marcelo A. Gil, and Maria A. C. de Godoy. Project supported by FAPESP (1998/16446-6) and CNPq (462629/00-7).

\section{REFERENCES}

AMBROSANO, E.J. Dinâmica do nitrogênio dos adubos verdes, crotalária júncea (Crotalaria juncea) e mucuna-preta Mucuna aterrima), em dois solos cultivados com milho. Piracicaba, 1995. 83p. Tese (Doutorado) Escola Superior de Agricultura "Luiz de Queiroz", Universidade de São Paulo

AMBROSANO, E.J.; TRIVELIN, P.C.O.; MURAOKA, T. Técnica para marcação dos adubos verdes crotalária júncea e mucuna-preta, com ${ }^{15} \mathrm{~N}$ para estudos de dinâmica do nitrogênio. Bragantia, v.56, p.219224, 1997
AZAM, F.; MALIK, K.A.; SAJJAD M.I. Transformations in soil and availability to plants of ${ }^{15} \mathrm{~N}$ applied as inorganic fertilizer and legume residues. Plant and Soil, v86, p.3-13, 1985.

BARTHOLOMEW, W.V. Mineralization and immobilization of nitrogem in the decomposition of plant and animal residues. In: BARTHOLOMEW, W.V. CLARK, F.E. (Ed.) Soil Nitrogen. Madison: ASA, 1965. p.287-306.

BATAGLIA, O.C.; FURLANI, A.M.C.; TEIXEIRA; J.P.F.; FURLANI, P.R GALLO, J.R. Métodos de análises químicas de plantas. Campinas Instituto Agronômico, 1983. 48p. (Boletim Técnico, 78).

BREMNER, J.M. MULVANEY, C.S. Nitrogen-Total. In: PAGE, A.L.; MILLER, R.H.; KEENEY, D.R. (Ed.) Methods of Soil Analysis. 2.ed. Madison: ASA, 1982. cap.31, p.595-624. (Agronomy, 9).

MASCARENHAS, H.A.A; TANAKA, R.T.; COSTA, A.A.; ROSA, F.V.; COSTA V.F. Efeito residual das leguminosas sobre o rendimento físico e econômico da cana-planta. Campinas: Instituto Agronômico, 1994. 15p (Boletim Científico, 32).

MURAOKA, T. Utilização de técnicas nucleares nos estudos da adubação verde. In: ENCONTRO SOBRE ADUBAÇÃO VERDE, Rio de Janeiro, 1983. Anais. Campinas: Fundação Cargill, 1984. p.330.

MURAOKA, T.; AMBROSANO, E.J.; ZAPATA, F.; BORTOLETTO, N.; MARTINS, A.L.M.; TRIVELIN, P.C.O.; BOARETTO, A.E.; SCIVITTARO, W.B. Eficiência de abonos verdes (crotalária y mucuna) y urea, aplicados solo o juntamente, como fuentes de $\mathrm{N}$ para el cultivo de arroz. Terra, (México),v.20, n.3 p.17-23, 2002

SALGADO, A.L.B.; BULISANI, E.A.; BRAGA, N.R.; MIRANDA, M.A.C. de. Crotalária júncea, In: INSTITUTO AGRONÔMICO (Campinas). Instruções agrícolas para o Estado de São Paulo. 4.ed. Campinas, 1987. p.81-82. (Boletim, 200)

TANAKA, R.T.; MASCARENHAS, H.A.A.; DIAS, O.S.; CAMPIDELLI, C. BULISANI, E.A. Cultivo de soja após incorporação de adubo verde e orgânico. Pesquisa Agropecuária Brasileira, v.27, p.1477-1483, 1992.

TRIVELIN, P.C.O.; SALATI, E.; MATSUI, E. Preparo de amostras para análise de ${ }^{15} \mathrm{~N}$ por espectrometria de massas. Piracicaba: CENA, 1973. 41p. (Boletim Técnico, 2)

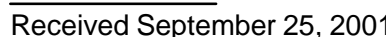

